\author{
Barbara Braun \\ University of Warsaw \\ Faculty of Geography and Regional Studies \\ Department of Geoecology \\ e-mail: bjbraun@uw.edu.pl
}

\title{
COLLUVIC UMBRISOLS AS A RESULT OF THE EROSION PROCESS OF ROLLING AND HILLY COUNTRY IN AGRICULTURAL AREA
}

\begin{abstract}
Agricultural activity, especially agricultural mechanization, leads to acceleration of erosion in rolling and hilly country. The level of the erosion process, already during territorial observations, may be assessed by the thickness of the humus horizon. In the vicinity of Bytów, the deluvial humus horizons have even achieved thickness of $100 \mathrm{~cm}$. These horizons are also richer in organic matter than humus horizons located on flat-topped mountains and mountain sides. Deluvial horizons are characterized by a somewhat less acid reaction, sometimes even neutral, and somewhat greater dehydration of the sorption complex by alkaline cations.
\end{abstract}

Key words: Colluvic Umbrisols, thickness of the humus horizon, fractional composition of humus, reaction, dehydration of the sorption complex by alkaline ions.

\section{INTRODUCTION}

Agricultural activity in an area of large land denivelation often leads to erosion of the humus horizon. Erosion caused by plough and cultivation includes levels of eluviation, enrichment or parent rock which is manifested by depletion of organic matter in soil. However, thick humus horizon is often found in areas of land denivelation. Washing away the humus horizon is one of the causes for soil depletion of both humus and nutrients which are stored in it (Gliński, Turski, 1976; Marcinek, Komisarek, 2001; Paluszek, Żembrowski, 2008).

\section{SUBJECT, OBJECTIVE AND METHOD OF RESEARCH}

The area which is the subject of research is located in northern Poland, in the vicinity of Bytów, in the mezoregions of Pojezierze Kaszubskie (Kaszuby Lake District) and Wysoczyzna Polanowska (Polanowska Plateau). In an 
area of about $900 \mathrm{~km}^{2}$ about 30 soil pits were dug and several dozen holes were drilled. Observations comprised both arable land of great area farms (land of the former state-owned farms) and small area farms which, for the past several dozen years, have been cultivated by individual farmers.

The research objective includes an attempt to assess the level of erosion in areas of diversified land sculpture by measuring the humus horizon and evaluation of the quality of deluvial soils on the basis of the following characteristics: reaction, organic carbon content, relation of fulvic acid to humic acid and dehydration of the sorption complex by acid and alkaline cations.

Observations included different types of soil which were formed by postglacial Vistula River glaciation deposits, the Pomeranian Phase. In sand deposits, in general of outwash deposit origin, Brunic Arenosols was formed, mainly rusty. In argillaceous deposits, boulder sands, often with a large content of dust, Cambisols were formed (with domination Luvisols) and in land depressions there are Histosols (Drainic Histosols) which are often covered with deluvial deposits.

The following methods were used to specify soil characteristics:

- granulometric composition by the Bouyuocosa - Casagrande' areometric method, modified by Prószyński (Bednarek et al., 2004),

- reaction in $1 \mathrm{M} \mathrm{KCl}$ potentiometric method (Bednarek et al., 2004),

- organic carbon (Corg) by the Tiurin method (Bednarek et al., 2004; Kononowa, 1968),

- hydrolytic acidity (Hh) and the total exchangeable alkaline cation (S) by the Kappen method and from their sum the absorbing capacity was calculated $(\mathrm{T}=\mathrm{Hh}+\mathrm{S})$ (Bednarek et al., 2004),

- fractional composition of humus according to the Kononowa and Bielczikowa method (Kononowa, 1968).

\section{RESULTS AND DISCUSSION}

Most often, arable soils from the Bytów vicinity show grain size bipartition. The upper part of the profile, do the depth of about $50-70 \mathrm{~cm}$, is constructed from argillaceous deposits, often with a large share of dust, whereas the lower part of the profile shows light and sandy-silty clay grain size.

In the rolling and hilly country, characteristic of the Bytów area, in land depressions, even 1 meter thick humus horizons are often found (Fig. 1). Most often they are made up of several layers which differ color and grain size. Often, peat deposits of different degree of dispersion are the substratum of these soils. The standard thickness of the humus horizon for arable land is $25-35 \mathrm{~cm}$. This depends on the depth of plowing. 


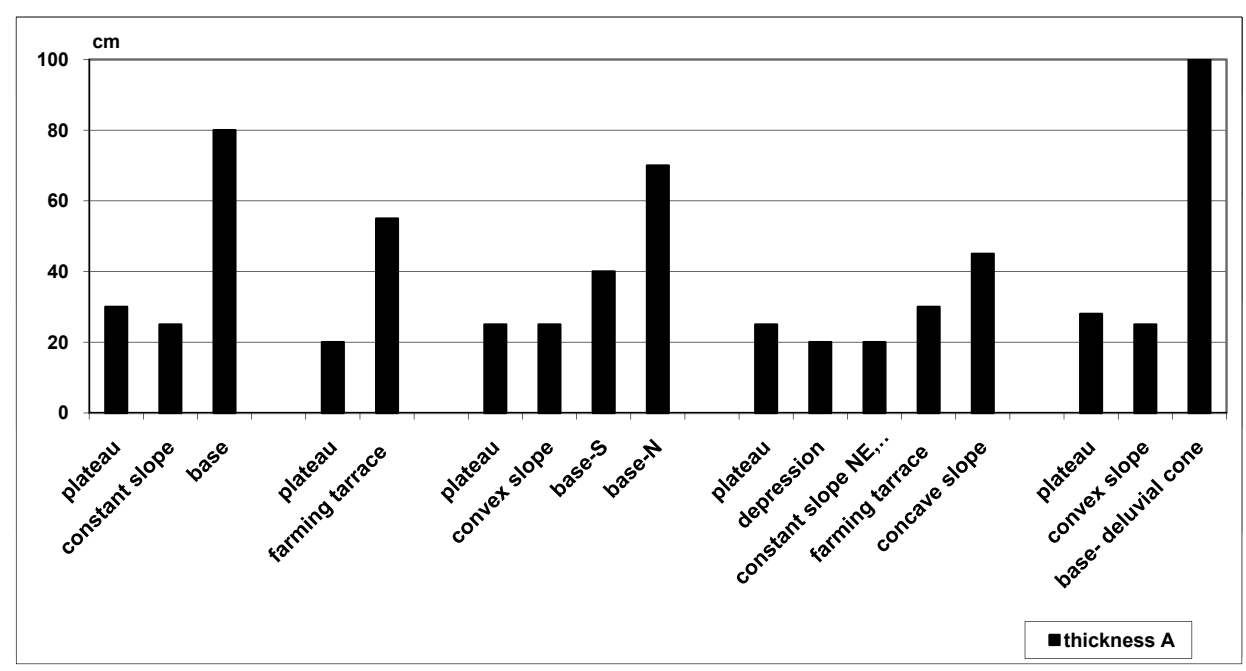

Fig. 1. Thickness of the humus horizon in facies (own study)

Such thickness of the humus horizon was confirmed on plateaus, on uniform and convex-uniform sloped hillsides and at foothills of concave slopes. On convex slopes, the thickness of the humus horizon was less than $20 \mathrm{~cm}$ and often this horizon did not exist at all. This indicates total destruction of the humus horizon by agricultural equipment and surface flow during intensive rainfall. A similar phenomenon of erosion of humus horizons in the rolling and hilly country was observed by Marcinek and Komisarek (2001) in the soils of the Wielkopolska Voivodeship. The greatest thickness of the deluvial humus horizons was observed in the area of uniformly sloped and convex foothills. In the case of uniformly sloped hillsides, the gradient is of no greater significance because large thickness of the deluvial horizons was observed both at a slope of $5 \%$ as well as $15 \%$. Such great loss of the humus horizon was not observed in places where agricultural routes and boundary strips exist. This confirms the regularity that arable land used in accordance with contour-lines and benching them prevents displacement of organic matter to plains beneath slopes.

Sodding the slopes also prevents displacement of humus down the slope. Thickness of the humus horizon under green crops varies between $30-50 \mathrm{~cm}$, both in the area of a plateau as well as on a slope. If the field was earlier arable land then small deepening of the humus horizon takes place in an area where the slope levels out.

The organic carbon content in the soil of Bytów county is between 0,9\% in the humus horizon of Luvisols (on peaks and slopes) and even $4 \%$ in deluvial horizons (Fig. 2). Obscured organic soils are the richest in organic matter. There, the organic matter content oscillates between 60 and 95\%.

High content of organic matter and thick humus horizons in Colluvic Umbrisols condition large accumulation of organic matter in these soils. It 
even amounts up to $300 \mathrm{t} \cdot \mathrm{ha}^{-1}$. Distribution of organic matter on hilltops does not depend on the slope type. Greater organic matter content on some slopes rather stems from organic fertilizing which is more often used on small area farms (Fig. 2, profile 1).

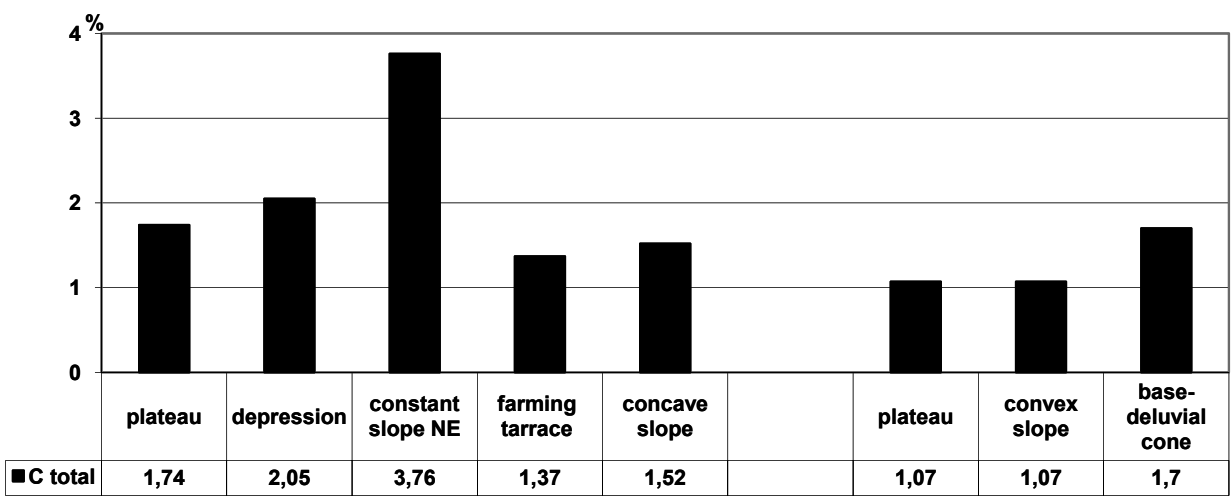

Fig. 2. Content of organic carbon in facies (own study)

The fractional humus content informs about the quality and degree of its transformation (Kononowa, 1968). Greater fulvic acid content is found in less fertile soils. Soils with a greater fulvic acid content are characterized by a tendency to wash away the soil profile and, what is associated with this, washing out diverse mineral elements. The fractional content of humus shows a certain link with erosion processes in soil. On the basis of analyses which have been carried out it is to be concluded that fulvic acids dominate on plateaus, uniformly sloped hillsides and at foothills (Fig. 3.) On convex slopes fulvic acid and humic acid content is equal and sometimes distinguishes itself by a slightly higher humic acid content (Fig. 3).

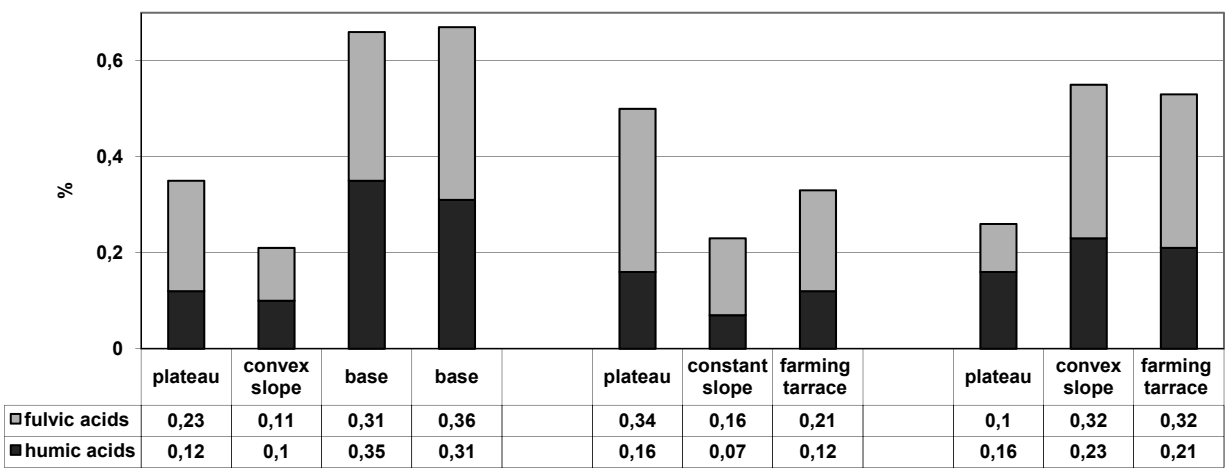

Fig. 3. Fulvic and humic acid content in humus in the plateau-slope-foothill pattern (own study) 
The deluvial horizons are usually characterized by a somewhat higher reaction than humus horizons at an elevation or on a slope. The reaction of deluvial horizons oscillates between 4,6 even up to $7 \mathrm{pH}$ and is, at minimum, half $\mathrm{pH}$ unit higher than its value on a plateau and a slope (Fig. 4, profile $1,2,3)$. This stems from the down hill flow of mineral elements together with humus, including alkaline compounds which are mobile in acidic reactions (Lecomte, Le Bissonais, 1999). On plateaus, convex slopes and universally sloped hillsides soil reaction is similar. The picture of reaction is different on concave slopes. The least acid reaction is associated with a concave slope where humus and mineral elements accumulate (Fig. 4). A small inflow of mineral elements to the bottom of a concave hill may lead to acidification and depletion of alkaline cations (Fig. 4, profile 4 in a depression).

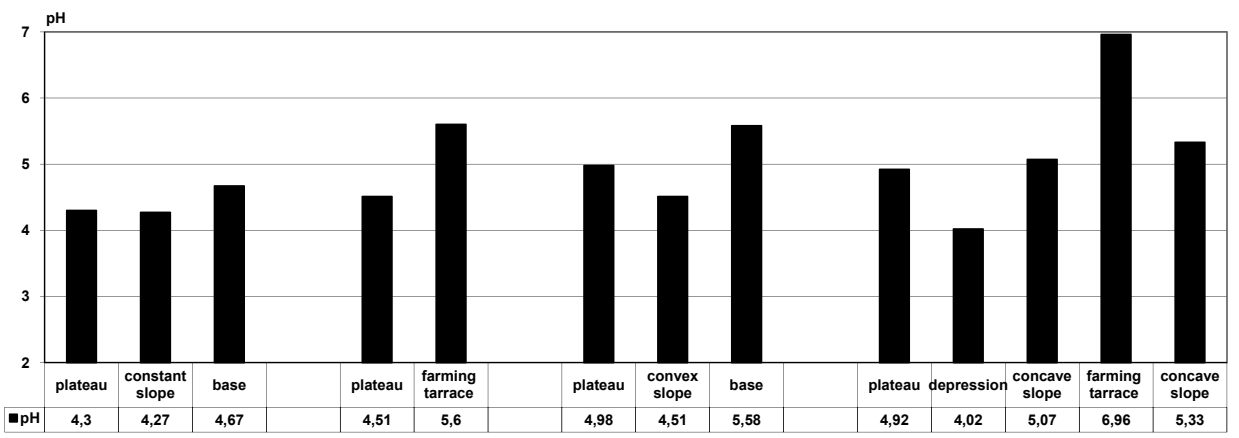

Fig. 4. Soil re action in facies (own studies)

Despite an acid reaction, alkaline cations dominate in the sorption complex of humus horizons in soil. They constitute about $50-60 \%$ of the cations in the sorption complex of the examined soils.

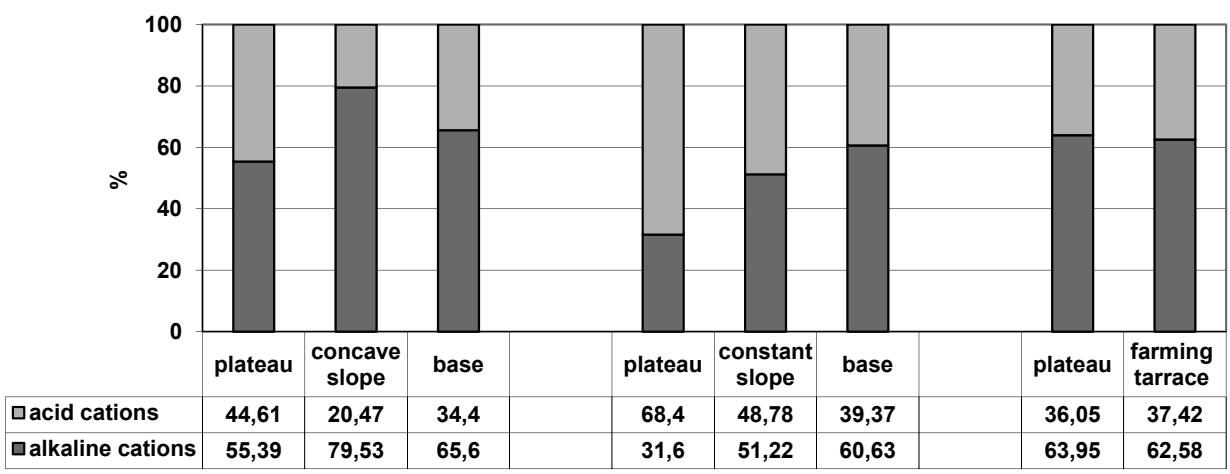

Fig. 5. Dehydration by acid and alkaline cations of the sorption complex in the soil humus horizon in facies (own study) 
An equilibrium between acid and alkaline cations in the sorption complex has been confirmed in areas of dissimilar landscape. Sometimes, as in the case of uniformly sloped hilltops, a greater amount of acid cations is observed on plateaus in the sorption complex. These facies are characterized by acid reaction, in general not exceeding $5 \mathrm{pH}$ (Fig. 5, profile 2,3 ). In an acid reaction alkaline cations are more easily released from the sorption complex and dislocated into the depth of a profile or on the slope. It may be assumed that the acid reaction of soils facilitates easy access of alkaline compounds to plants. It has been observed that on concave slopes there is a somewhat higher alkaline cation content in the sorption complex than on plateaus or by foothills (Fig. 5, profile 1). This indicates retention of solutions containing cations on the stock. Cultivation of subhumus horizons on the slopes may lead to the enrichment of the sorption complex by alkaline cations which has been proven by Paluszka (2004) in soils formed from loess.

\section{CONCLUSIONS}

1. Thickness of the humus horizon in the plateau-slope-foothill pattern may be a good indicator of accumulation of material from erosion by water and cultivation. At the bottom of a hill deluvial thickness may even reach one meter.

2. Often, the color of the humus horizon on slopes is somewhat lighter than on plateaus and in areas leveling off by foothills which indicates ploughing of the subsoil horizon. This phenomenon is very well visible during field research.

3. In thick deluvial soil, the organic matter content may amount to even $300 \mathrm{t} \cdot \mathrm{ha}^{-1}$. On plateaus and slopes, organic matter reserves are decidedly smaller and amount to about 150-180 $\mathrm{t} \mathrm{ha}^{-1}$.

4. Colluvic Umbrisols indicate higher $\mathrm{pH}$ values than humus horizons on plateaus and slopes. This phenomenon is associated with greater dehydration of the sorption complex by alkaline cations. With an acid reaction these cations are mobile and may move down the slope together with the humus and accumulate at the bottom of the slope.

\section{REFERANCES}

1. Bednarek R., Dziadowiec H., Pokojska U., Prusinkiewicz Z., 2004, Badania ekologiczno-gleboznawcze [Research on ecology and pedology], Wydawnictwo Naukowe PWN Warszawa.

2. Gliński J., Turski R., 1976, Rozwój procesów erozji gleb w zależności od sposobów zagospodarowania oraz uprawy mechanicznej i ich wpływ na kształtowania pokrywy glebowej [Development of soil erosion processes depending on manner of farming and mechanical cultivation and their impact on shaping of the soil cover], Zesz. Probl. Post. Nauk Rol., 177, 47-71;

3. Kononowa M., 1968, Substancje organiczne gleby [Organic soil substances]. PWRiL, Warszawa. 
4. Lecomte V., Le Bissonais Y., 1999, Transfert de pesticides par ruissellement et érosion de la parcelle au bassin versant, dans la région agricole du Pays de Caux. [in:] Wicherek S. (ed.), Paysages agraires et Énvironnement, CNRS, Paris, 239-251.

5. Marcinek J., Komisarek J., 2001, Przekształcenia pokrywy glebowej na skutek przyspieszonej erozji wodnej falistych i pagórkowatych terenów Niziny Wielkopolski [Transformation of the soil cover as a result of water erosion of rolling and hilly area of the Wielkopolska Lowlands]. Folia Univ. Agric. Stetinensis 217, Agricultura, 87, 135-146.

6. Paluszek J., 2004, Wpływ erozji wodnej na chemiczne właściwości gleb płowych wytworzonych z lessu [Impact of water erosion on the chemical characteristics of lessive soil fordem by loess], Rocz. Glebozn., 55 (4), 103-113.

7. Paluszek J., Żembrowski W., 2008, Ulepszanie gleb ulegających erozji w krajobrazie lessowym [Improvement of eroded soils in lessive landscape], Acta Agrophysica, 164 (4), 52-54.

English translation: Małgorzata Miłaszewska 